(RESEARCH ARTICLE)

\title{
Determination of percentage zinc loss during melting of zinc scrap in a crucible furnace
}

\author{
Onyekwere, Okwuchi Smith $1,{ }^{*}$ Orji, Chiawolamoke Ihenwokeleme ${ }^{2}$ and Uyanga, Kindness Alfred ${ }^{3}$ \\ ${ }^{1}$ Faculty of Engineering, Federal University Wukari Taraba State, Nigeria. \\ 2 Department of Welding and Fabrication, Abia State Polytechnic Aba, Nigeria. \\ ${ }^{3}$ School of Energy and Environment, City University of Hong Kong, Kowloon, Hong Kong.
}

Publication history: Received on 15 October 2019; revised on 02 December 2019; accepted on 04 December 2019

Article DOI: https://doi.org/10.30574/gjeta.2019.1.1.0004

\begin{abstract}
During the melting process of zinc scraps, not all the zinc metals in the scrap are recovered. This article evaluates the extent of zinc loss during melting of zinc scraps. Zinc scraps were melted in a charcoal-fired crucible furnace, and the percentage zinc loss was determined. Two modes of zinc loss were observed - zinc loss through evaporation and zinc loss through the dross. It was determined that 2.2 percentage of the total zinc was lost through evaporation while 10.8 percentage of the total weight was lost in the dross when zinc scrap was melted without fluxing. The total zinc loss when zinc scrap was melted without fluxing was found to be 13 percent. With fluxing, using chloride-salt based flux (17\% $\mathrm{KCl}, 20 \% \mathrm{NaCl}, 63 \% \mathrm{ZnCl}_{2}$ salt system), 0.79weight percent and 1.74 weight percent was lost through evaporation and dross respectively. The total zinc loss was reduced to 2.53 weight percent with fluxing. This work will help foundrymen in method and economic decision making when working on zinc scraps.
\end{abstract}

Keywords: Zinc Loss; Zinc Alloys; Dross; Zinc recovery; Zinc scrap

\section{Introduction}

Zinc alloys have been used in the production of various parts such as car carburettors, door handles, etc. Based on historical consumption, it is estimated that currently, 30-40\% of the cast zinc components used in manufacture are being recovered and recycled [1].Recycling zinc alloys from scraps has energy savings advantage over processing zinc composites. The ability to melt zinc scrap many times without losing its properties is of significant benefit to the zinc die caster. However, it is important to keep the material clean and free of unwanted substances [2].

Despite cleaning of the scraps, oxide films and some unwanted substances are also found in the zinc melt. When an alloy melt reacts with the atmosphere or moisture, it forms an amorphous continuous oxide film on the surface of the bath. These oxide films are an essential part of the melting process because they protect the metal underneath from further oxidation. Also, during the melting of the scraps, some have inserts that may not be very economical to remove before the melting operation. Some of the inserts made of iron and aluminium will dissolve in the zinc melt up to their respective solubility limits. Dissolution above their solubility limit will cause the formation of intermetallic compounds, in particular, the zinc-iron and zinc-iron-aluminium compounds with high proportions of entrained zinc [3]. In the process of removing these unwanted substances, zinc will be lost.

Zinc dross is a mixture of metallic materials contained in a matrix of zinc. During melting of zinc scrap, the intermetallic compounds formed will adversely affect the wetting characteristics of the zinc slag, causing the dross to encapsulate free zinc metal; thus the resultant dross is rich in metallic zinc which cannot easily be mechanically separated. Skimming out the dross will mean substantial loss in the zinc metal. In foundry operations, the surface of the molten bath is always moving due to charging, skimming, cleaning, transferring, ladling, etc. Any of these melting practices causes the thin film

\footnotetext{
${ }^{*}$ Corresponding author

E-mail address: smithonyekwere@gmail.com
} 
to break and re-oxidize, thus causing rapid oxide film thickening [4]. The movement and breaking of these oxide films cause the films to crumble, to thicken and to encapsulate unoxidized molten metal, generating wet dross. Dross is considered to be a main contributor to total metal loss during melting [5].

Before pouring the liquid metal into the mould, the dross needs to be skimmed out to avoid inclusions in the castings. The amount of zinc metal lost after the dross has been skimmed out was evaluated in this study. This study also compared the amount of zinc lost when flux was used and when flux was not used. The flux used is chloride-salt based flux formulated by the authors from $\mathrm{KCl}, \mathrm{NaCl}, \mathrm{ZnCl}_{2}$ and other additives.

\section{Material and methods}

To evaluate the amount of zinc lost during the melting of zinc alloys, zinc scraps were collected, dismantled and thoroughly washed to remove surface contaminants and later dried in air. The parts were then broken to pieces and weighed into five sets of above $100 \mathrm{~g}$ each. Each set was put in a small crucible and then heated to molten state at a temperature of $580^{\circ} \mathrm{C}$. After stirring thoroughly, the melt was allowed to settle so that the dross can float to the surface for easy removal. Deslagging ladle was used to remove the dross and inserts/attachments. Then, the dross was dropped on a hot steel gauze where time was allowed for all the liquid zinc in the dross to drip out before collection.

After the removal of the dross, the melt was poured into a metallic mould where it solidified. The weight of the solidified zinc metal was weighed and recorded. The weight of the dross and inserts were recorded. Table 1 shows the result obtained from the experiment. The experiment was first conducted without fluxing and then with fluxing using $17 \%$ Potassium chloride(KCl), $20 \%$ Sodium chloride $(\mathrm{NaCl})$, and $63 \%$ Zinc chloride $\left(\mathrm{ZnCl}_{2}\right)$ salt system. The following parameters were then calculated:

\subsection{Weight of zinc scrap}

The weight of the scrap, which includes the weight of inserts and other impurities, was obtained and represented as $\mathrm{W}_{\mathrm{s}}$.

\subsection{Weight of zinc in the scrap}

This was obtained after the scrap had been cleaned and the inserts removed. Weight of zinc in the scrap,Wz, was calculated using Equation 1

$$
\mathrm{Wz}=\mathrm{Ws}-\mathrm{Wi}
$$

where Ws is the weight of zinc scrap and Wi is the weight of the inserts.

\subsection{Weight of recovered zinc}

The weight of the recovered zinc, Wr, was calculated using Equation 2.

$$
\mathrm{Wr}=\mathrm{Wz}-\mathrm{We}-\mathrm{Wd}
$$

Where $\mathrm{Wz}$ is the weight of zinc in the scrap, We is the weight of zinc lost through evaporation, and Wd is zinc weight loss through dross.

\subsection{Zinc loss through evaporation}

The weight of zinc loss through evaporation, We, was calculated using Equation 3.

$$
\mathrm{We}=\mathrm{Wz}-\mathrm{Wr}-\mathrm{Wd}
$$

where $\mathrm{Wz}$ is the weight of zinc in scrap, Wr is the weight of recovered zinc and $\mathrm{Wd}$ is the weight of the dross.

The parameters were used to calculate the percentage of zinc loss.

\section{Results and discussion}

When zinc alloy was melted, the result obtained shows that some amount of zinc was lost as the dross was skimmed out (Table 1). While $10.77 \%$ of the zinc was lost through dross, $2.22 \%$ was lost through evaporation without fluxing, 
bringing the total amount of zinc lost to $12.99 \%$ of the original zinc metal that was melted. This is illustrated in Figure 1 and Figure 2.

Table 1 Zinc losses during the melting of zinc scrap without fluxing.

\begin{tabular}{lllllllllll}
\hline RUNS & $\begin{array}{l}\text { Wt. of } \\
\text { zinc } \\
\text { scrap } \\
\text { (g) }\end{array}$ & $\begin{array}{l}\text { Wt. of } \\
\text { insert } \\
\text { s }\end{array}$ & $\begin{array}{l}\text { (g) } \\
\text { zinc } \\
\text { in the } \\
\text { scrap } \\
\text { (g) }\end{array}$ & $\begin{array}{l}\text { Wh } \\
\text { dross } \\
\text { (g) }\end{array}$ & $\begin{array}{l}\text { Wt. of } \\
\text { recov } \\
\text { ered } \\
\text { zinc } \\
\text { (g) }\end{array}$ & $\begin{array}{l}\text { Wt. loss } \\
\text { through } \\
\text { evapora } \\
\text { tion (g) }\end{array}$ & $\begin{array}{l}\text { \% Zinc } \\
\text { recover }\end{array}$ & $\begin{array}{l}\text { \% } \\
\text { loss } \\
\text { through } \\
\text { evaporati } \\
\text { on }\end{array}$ & $\begin{array}{l}\text { \% mass } \\
\text { loss } \\
\text { through } \\
\text { dross }\end{array}$ & $\begin{array}{l}\text { \% Total } \\
\text { mass } \\
\text { loss }\end{array}$ \\
\hline 1 & 109 & 4 & 105 & 11 & 92 & 2 & 87.61 & 1.90 & 10.47 & 12.38 \\
2 & 105 & 2 & 103 & 10 & 90 & 3 & 87.3 & 2.91 & 9.70 & 12.62 \\
3 & 113 & 3 & 110 & 15 & 94 & 1 & 85.45 & 0.90 & 13.63 & 14.54 \\
4 & 107 & 0 & 107 & 13 & 92 & 2 & 85.98 & 1.86 & 12.14 & 14.01 \\
5 & 104 & 3 & 101 & 8 & 90 & 3 & 89.10 & 2.97 & 7.92 & 10.89 \\
Average & 107.6 & 2.4 & 105.2 & 11.4 & 91.6 & 2.2 & 87.10 & 2.11 & 10.77 & 12.89 \\
\hline
\end{tabular}

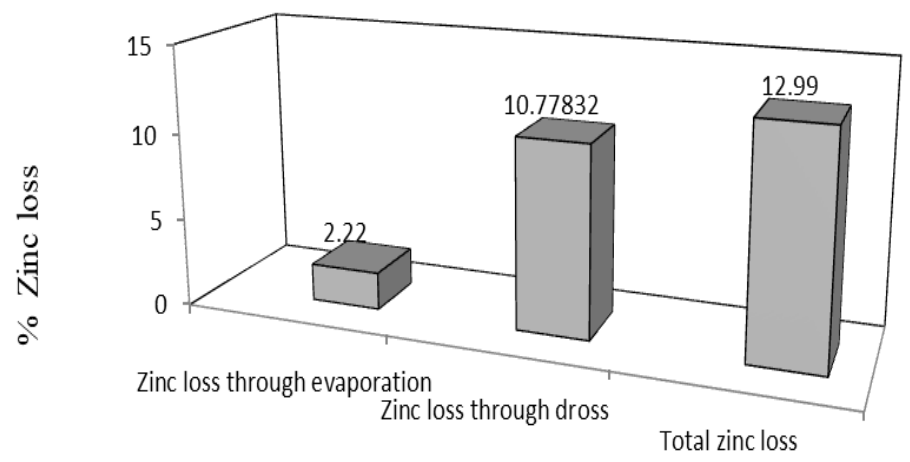

Figure 1 Zinc losses through dross, evaporation and the total zinc loss (without the use of flux)

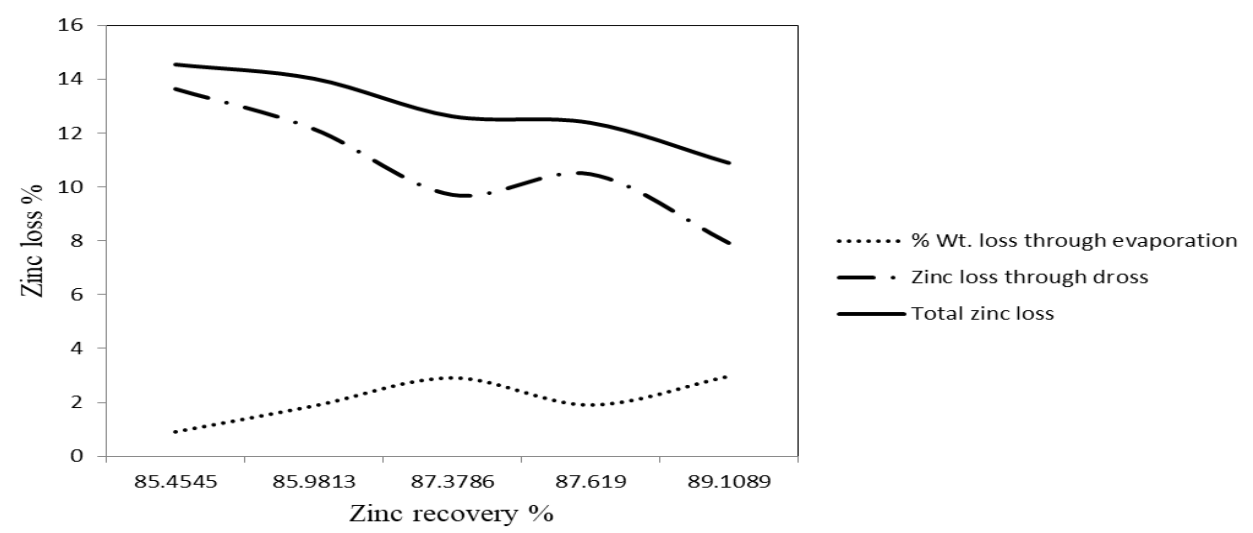

Figure 2 Relationship between zinc recovery and zinc losses through dross, evaporation and the total zinc loss (without the use of flux) 
From Figure 1, it is evident that most of the zinc is lost through the formation of dross while a very small amount is through evaporation. A careful look at Figure 2 shows that there is an inverse relationship between the amount of zinc recovered and the amount of dross generated. When more zinc is recovered, the quantity of dross generated is less, which shows that the dross is a product that formed mostly from zinc, while the presence of other impurities contribute since the plot did not show a linear relationship between the two variables. The plot depicts a polynomial relationship given in Equation 4.

$$
\mathrm{Zn}_{\mathrm{LD}}=-0.445 \mathrm{Zn}_{\mathrm{R}}{ }^{4}+5.149 \mathrm{Zn}_{\mathrm{R}}{ }^{3}-20.23 \mathrm{Zn}_{\mathrm{R}}^{2}+29.85 \mathrm{Zn}_{\mathrm{R}}-0.686
$$

where $\mathrm{Zn}_{\mathrm{LD}}$ represents the\% zinc loss through dross while $\mathrm{Zn}_{\mathrm{R}}$ represents the \% zinc recovery.

The zinc loss through evaporation is small and can be related to the zinc recovered by the relationship given in Equation 5.

$$
\mathrm{Zn}_{\mathrm{LE}}=0.260 \mathrm{Zn}_{\mathrm{R}}{ }^{4}-2.963 \mathrm{Zn}_{\mathrm{R}}{ }^{3}+11.30 \mathrm{Zn}_{\mathrm{R}}{ }^{2}-16.11 \mathrm{Zn}_{\mathrm{R}}+8.425
$$

where $\mathrm{Zn}_{\mathrm{LE}}$ is the zinc loss through evaporation. The total zinc loss $\mathrm{Zn}_{\mathrm{LT}}$ can be evaluated through the zinc recovered using Equation 6.

$$
\mathrm{Zn}_{\mathrm{LT}}=-0.184 \mathrm{Zn}_{\mathrm{R}}^{4}+2.185 \mathrm{Zn}_{\mathrm{R}}^{3}-8.929 \mathrm{Zn}_{\mathrm{R}}^{2}+13.73 \mathrm{Zn}_{\mathrm{R}}+7.739
$$

where

$$
\mathrm{Zn}_{\mathrm{LT}}=\mathrm{Zn}_{\mathrm{LD}}+\mathrm{Zn}_{\mathrm{LE}}
$$

In Table 2, the percentage of zinc loss with and without flux was compared. It was found that 86.99 wt $\%$ of the scrap zinc was recovered without fluxing while $98.10 \mathrm{wt} \%$ were recovered using chloride salt-based fluxing agent. This indicates that fluxing leads to the recovery of additional $11.11 \mathrm{wt} \%$ zinc during zinc scrap re-melting over unfluxed remelting.

Table 2 Weight percentage zinc recovered with and without fluxing

\begin{tabular}{llllllll}
\hline $\begin{array}{l}\text { Fluxing } \\
\text { Condition }\end{array}$ & Trials & $\begin{array}{l}\text { Weight } \\
\text { Before } \\
\text { Recycling (g) }\end{array}$ & $\begin{array}{l}\text { Weight After } \\
\text { Recycling (g) }\end{array}$ & $\begin{array}{l}\text { Weight } \\
\text { of Dross } \\
\text { (g) }\end{array}$ & $\begin{array}{l}\text { Wt\% lost } \\
\text { through } \\
\text { Evaporation }\end{array}$ & $\begin{array}{l}\text { Wt\% lost } \\
\text { through } \\
\text { Dross }\end{array}$ & $\begin{array}{l}\text { Wt\% Zinc } \\
\text { Recovered }\end{array}$ \\
\hline Without Flux & 1 & 107 & 92 & 13 & 1.86 & 12.14 & 85.98 \\
& 2 & 105 & 92 & 11 & 1.90 & 10.47 & 87.62 \\
& 3 & 103 & 90 & 10 & 2.91 & 9.71 & 87.38 \\
& Average & & & & 2.22 & 10.77 & 86.99 \\
With Flux & 1 & 107 & 105 & 2 & 0.93 & 1.86 & 98.13 \\
& 2 & 105 & 103 & 1.5 & 0.48 & 1.43 & 98.10 \\
& 3 & 103 & 100 & 2 & 0.97 & 1.94 & 97.10 \\
& Average & & & & 0.79 & 1.74 & 98.10 \\
\hline
\end{tabular}

\section{Conclusion}

The amount of zinc lost when a zinc scrap is melted with and without the use of fluxing agents was examined. It was found that only $86.99 \mathrm{wt} . \%$ of the zinc was recovered after melting without fluxing. $2.22 \%$ of the zinc metal was lost through evaporation, $10.77 \%$ was lost through untreated dross giving a total loss of $12.99 \mathrm{wt} . \%$. With the application of chloride-salt based flux formulated by the authors, $98.10 \mathrm{wt} \%$ of the zinc scrap was recovered after melting. $0.79 \mathrm{wt} . \%$ of the zinc metal was lost through evaporation while $1.74 \mathrm{wt} \%$ was lost through untreated dross giving a total loss of 3.01wt.\%. This study should serve asis a reference work for foundrymen in decision making. Foundrymen that want to 
use this method for melting of zinc scrap need to consider the tradeoff between zinc loss without flux agent and the cost of fluxing agent.

\section{Compliance with ethical standards}

\section{Acknowledgements}

The authors are grateful to Cokee Foundries Limited, Aba for the use of their facilities to carry out the experiments and for their technical inputs during the research work.

\section{Disclosure of conflict of interest}

There is no conflict of interest in this work.

\section{References}

[1] ZDA and ZADCA. (1990). Environmental Aspects of Zinc Alloy Die Casting. ZDA, London, 8-11.

[2] Frank EG. (2008). Hot Chamber Die Casting. ASM Handbook, 15, 722.

[3] OrjiCI. (2010). The Effects of Additions of NaCl-KCl-ZnCl2 Salt Mixture on The Fluxing of Recycled Zinc Alloys. MEng. Thesis, Federal University of Technology Owerri, Nigeria, 34- 40.

[4] Mishra R and Dutta M. (2007). Effect of Steel Composition on Iron Dissolution in Molten Zinc and Development of Fe-Zn Phases on Steel Surface, ISIJ International, 47 (10), 1504-1509.

[5] Gallo R. (2002). Development, Evaluation and Application of Solid Fluxes. AFS Transactions, American Foundry Society, Inc., (2002), 267-270.

\section{How to cite this article}

Onyekwere OS Orji CI and Uyanga KA. (2019). Determination of percentage zinc loss during melting of zinc scrap in a crucible furnace. Global Journal of Engineering and Technology Advances, 1(1), 22-26. 